\title{
Percutaneous transforaminal Endoscopic Lumbar Discectomy: Early Experience of the First Fifty 50 cases
}

\author{
AYMAN M. ISMAIL, M.D.*; ESAM ABDELHAMID DAOUD, M.D.* and \\ IHAB ALY MOHAMED HOSNY, M.D.** \\ The Department of Neurosurgery, Faculty of Medicine, Zagazig University, Egypt* and \\ Orthopedics, Egyptian Military Medical Academy**
}

\begin{abstract}
Background: Many surgical approaches from standard discectomy, microdiscectomy, percutaneous interlaminar and transforaminal endoscopic discectomy have been used for treatment of prolapsed intervertebral disc. Transforaminal endoscopic discectomy through a Kambin triangle is a minimal invasive procedure which can be done under local anesthesia, without muscle splitting, with short hospital stay and minimal complications.

Aim: The aim of this study is evaluation of early experience of transforaminal endoscopic lumbar discectomy, surgical technique, complications, and overall results.

Patients \& Methods: A retrospective study involved fifty patients with low back pain and unilateral sciatica due to prolapsed intervertebral disc were treated with endoscopic transforaminal discectomy at neurosurgery department( Zagazig University Hospitals) and Al Helmia military hospital from June2017 to December 2018 (35 patients under local, 15 patients under general anesthesia).Visual analogue score (VAS) and Oswestry Disability Index (ODI) has been used for preoperative clinical assessment of the patients, follow up was done at 1,6 and 12, months postoperatively. Modified Mac Nab's criteria used for evaluation of the outcome.

Results: Using Modified MacNab's criteria, good to excellent outcome was noted (43 patients, $86 \%$ ), fair outcome (3 patients, 6\%) and poor results (4 patients, $8 \%)$. No major complications were noted, discits in $(2$ patients, 4\%), dysaethesia (3 patients, 6\%), recurrent disc prolapsed (5 patients, $10 \%)$,dural tear in ( 2 patients, $4 \%$ ), one case of superficial wound infection ,mean operative time was $72.60 \pm 16.90$ minutes, mean hospital stay (14.76 \pm 11.20 hours), mean return to work was $26.36 \pm 6.33$ days.
\end{abstract}

Correspondence to; Dr. Ayman M. Ismail, E-Mail: aymanmismael@gmail.com
Conclusion: The Percutaneous transforaminal discectomy has been advanced over the last decades and become an accepted, safe and successful choice for management of lumbar disc prolapse and associated sciatica in selected patients, although the microdiscectomy remains the gold standard one.

Key words: Transforaminal, Endoscopic - Kambin Lumbar - Discectomy

\section{Introduction}

PROLAPSED intervertebral disc is one of the most common pathological spinal disorders which needs surgery between the other causes of low back pain $[1,2]$. The first laminectomy and discectomy has been done by Oppenheim and Fedre Krause in 1906 [3] but Mixter and Bar have published it for the first time in 1934 [4], since that the laminectomy, hemilaminectomy, fenestration and microscopic discectomy were introduced and are still widely used all over the world. Trials for posterolateral discectomy through mechanical neucleotomy started by Hijikata followed by automated percutaneous discectomy by Onik $[\mathbf{5 , 6 ]}$. Percutaneous posterolateral approach had introduced by Kambin for treatment of herniated LDP, and it has refined over the last decades and becoming more popular as the treatment of choice in selected cases $[\mathbf{7 , 8}]$.

Yeung developed a rigid working channel endoscope for percutaneous endoscopic lumbar discectomy (PELD) or (YESS) technique. ${ }^{9}$ In TED the main targets are the pain generators without disturbing the posterior element of the spine. ${ }^{9,14}$ Major complications during TED such as vascular injury, nerve root injury and visceral injury are not common but may occurs due to lack of skills, improper learning and bad selection of the patients $[8,10]$. 


\section{Patients and Methods}

A total of fifty (50) patients who had treated with transforaminal endoscopic discectomy between June2017 to December 2018 with a mean follow up one year. The cases operated at Neurosurgical Department, Zagazig University Hospital and Al Helmia Military Hospitals. Informed written consents were obtained from the patients and approval from the Zagazig University review board (IRB) was taken

Inclusion criteria: 1) Patients with unilateral sciatica due to LDP and conservative treatment has failed for 6 weeks; 2) Recent MRI scan of lumbar spine revealed posterolateral contained disc prolapsed correlating with clinical presentation.

Exclusion criteria: 1) Patients of lumbar canal stenosis (central or lateral); 2) Bilateral sciatica; 3) Sciatica due to other pathologic conditions (fracture, trauma, tumour, infection); 4) Cases of cauda equine syndrome and old significant foot drop; 5) cases of complete disc collapse; 6) upper lumbar disc levels

\section{Operative technique:}

We have used Karl-Storz Gore endoscope with wide angle telescope $25^{\circ}$ oblique views and $3.5 \mathrm{~mm}$ working channel in this study.

All patients had a preoperative lumbosacral $\mathrm{X}$-rays, magnetic resonance imaging (MRI), CT LSS done in suspected cases of calcified discs. All preoperative laboratory investigations have done and $2 \mathrm{~g}$ triaxone intravenously has given as a routine antibiotic phophylaxis, patients were placed prone on a radiolucent operative table. The procedure was done under local anesthesia with monitoring except 15 patients have chosed GA. Local anesthesia with sedation (midazolam and fentanyl 100-200 mg), and nitrous oxide mask can be used when needed. All lumbar area painted with iodine and drapping has done wide enough. Skin, fascia, muscles were infiltrated with $1 \%$ lidocaine.

Needling: Initial needle placement guided by fluoroscopy is very important; it will determine the endoscopic view. The needle entry point typically starts about 10 to $14 \mathrm{~cm}$ from the midline, the entry point can be a little more medial or lateral according to the site of the disc. A 18 gauge aspiration needle (21 inch length) inserted from the entry point to land at the disc at the medial pedicular line in $\mathrm{A} / \mathrm{P}$ view and at posterior vertebral line in the lateral view, then the needle advanced to be in the midline in $\mathrm{A} / \mathrm{P}$ view $\mathrm{X}$-ray. The stylet of the needle removed, a guide wire was passed into the disc space and the needle was removed. Once the dilator passed over the guide wire, local anesthetic given by using the side channel. Check again the dilator was inside, remove the guide wire, put the operative sheath over the dilator, then dilator removed and the endoscope was inserted through the operation sheath. All of the cases operated by in-out technique alone or combined with half-half technique, the disc was seen directly and removed. We considered the surgery was satisfactory when; 1)a big disc fragment or considerable multiple disc fragments which removed matched with the MRI findings; 2) with visualization of epidural fat, dural cough pulsation and traversing root (sometimes we couldn't see the decompressed traversing nerve root). Bleeding during operation controlled by radiofrequency cautery. Once discectomy was finished, $1 \mathrm{ml}$ of $80 \mathrm{mg}$ depomodrol has been injected in the foramen, then the endoscope and operative sheath have been removed and wound closed with a single stitch.

Postoperatively: All patients were mobilized as soon as the pain subsides and discharged within 24 hours unless there were complications. Postoperative MRI has been done only when indicated.

Evaluation of the pain, functional disability and outcome results: Visual analogue scale (VAS, 0-10 points) had used for evaluating pre and postoperative pain, and Oswestry disability index (ODI) for the functional status. We had used these scores and indices preoperatively, one month, 6 months and after one year postoperatively. Outcome has been evaluated using a modified Mac Nab's criteria. Follow up sheets was filled out at discharge and with each visit.

Statistical analysis: All data were collected and analyzed using SPSS Version 19.0 (SPSS Inc., Chicago, IL, USA).

\section{Results}

\section{General data:}

Fifty patients included in the current study, 33 males (66\%) and 17 females (34\%).The mean age was $41.14 \pm 11.60$ years. LDP at L4-5 level was the most affected disc level and constituted (68\%) of the cases, followed by LS-S1 (18\%) and L3-4 (6\%). 47 (94\%)patients suffered from single level lesion and double disc lesions reported in 3 
patients $(6 \%)$ only. Right sciatica reported in 34 patients $(68 \%)$, and $\mathrm{Lt}$ sided sciatica in 16 patients(32\%). The mean operative time in our study was $72.60 \pm 16.90$ minutes. In our study the mean of hospital stay was $14.76 \pm 11.20$ hours and mean time to return to work was $26.36 \pm 6.33$ days.

\section{Evaluation of back pain:}

The mean VAS score for back pain preoperatively, 1,6, and 12 months postoperatively as follow $6.80 \pm 1.12, \quad 2.70 \pm 0.890$, $1.68 \pm 0.819,1.52 \pm 0.68$ respectively, all post operative follow up VAS values significantly decreased in relation to the preoperative back pain VAS.

\section{Evaluation of leg pain:}

In the current study, the mean VAS score for sciatica preoperatively, 1, 6, 12 months postoperatively as follow $7.64 \pm 0.76,2.32 \pm 0.74$, $1.80 \pm 0.78,1.54 \pm 0.696$ respectively, there was a high statistical Significant relation between VAS sciatica preoperatively and all post-operative values $(\mathrm{P}<0.001)$.

\section{Functional status evaluation:}

The mean ODI preoperatively, $6 \mathrm{~m} \&$ 12 months postoperatively as follow $41.68 \pm 0.476$, $23.76 \pm 2.42,14.60 \pm 2.68$, and statistically it was high significant $(\mathrm{P}<0,001)$.

Table (1): the results

\begin{tabular}{|c|c|c|}
\hline & $\mathrm{N}$ & $\%$ \\
\hline Number of patients & 50 & \\
\hline \multicolumn{3}{|l|}{$-\operatorname{sex}$} \\
\hline Male & 33 & $66 \%$ \\
\hline Female & 17 & $34 \%$ \\
\hline - Mean age & $41.14 \pm 11.60$ years & \\
\hline \multicolumn{3}{|l|}{ - Sciatica } \\
\hline $\mathrm{RT}$ & 34 & $68 \%$ \\
\hline LT & 16 & $32 \%$ \\
\hline \multicolumn{3}{|l|}{ - Disc level: } \\
\hline L4-9 & 34 & $68 \%$ \\
\hline LS-S1 & 9 & $18 \%$ \\
\hline L3-4 & 4 & $8 \%$ \\
\hline Two disc levels & 3 & $6 \%$ \\
\hline \multicolumn{3}{|l|}{ - Anesthesia: } \\
\hline Local & 35 & $70 \%$ \\
\hline General & 15 & $30 \%$ \\
\hline Mean operative time & $72.60 \pm 16.90$ minutes & \\
\hline Mean hospital stay & $14.76 \pm 11.20$ hours & \\
\hline Mean time to return to work & $\begin{array}{l}26.36 \pm 6.33 \\
\text { days }\end{array}$ & \\
\hline Mean VAS back pre-op & $6.80 \pm 1.12$ & Compared to pre-op back VAS, all \\
\hline Mean VAS back post-op 1month & $2.74 \pm 0.899$ & post-op values significantly decreased \\
\hline Mean VAS back post-op 6months & $1.68 \pm 0.819$ & with significant relation \\
\hline Mean VAS back post-op 12months & $1.52 \pm 0.677$ & $\begin{array}{l}(\mathrm{P}<0.001) \& b e t w e e n \text { post }- \text { op } 6 \text { and } 12 \\
\text { months VAS }(\mathrm{p}=0.010)\end{array}$ \\
\hline Mean VAS sciatica pre-op & $7.54 \pm 0.93$ & Significant relation between preo-op \\
\hline Mean VAS sciatica post-op 1 month & $2.32 \pm 0.74$ & VAS (sciatica) and post-op $1,6,12$ \\
\hline Mean VAS sciatica postop 6months & $1.80 \pm 0.782$ & months respectively, high \\
\hline - Mean VAS sciatica postop 12 months & $1.54 \pm 0.696$ & $\begin{array}{l}\text { significanse, } \mathrm{P}<0.001) \quad \text { significance } \\
\text { between } 6 \text { and } 12 \mathrm{~m} \text { VAS }(\mathrm{p}=0.041)\end{array}$ \\
\hline \multicolumn{3}{|r|}{ (2) } \\
\hline Pre op & $41.68 \pm 0.476$ & High significanse \\
\hline Post op $6 \mathrm{~m}$ & $23.76 \pm 2.42$ & $(\mathrm{P}<0.000)$ \\
\hline Post op $12 \mathrm{~m}$ & $14.60 \pm 2.68$ & \\
\hline - Complication rate related procedure & 8 & $16 \%$ \\
\hline - Recurrence rate & 5 & $10 \%$ \\
\hline \multicolumn{3}{|l|}{ - Mac Nab's outcome criteria: } \\
\hline Excellent & 29 & $58 \%$ \\
\hline Good & 14 & $28 \%$ \\
\hline Fair & 3 & $6 \%$ \\
\hline Poor & 4 & $8 \%$ \\
\hline
\end{tabular}


Table (2): Complication related procedure:8 patients(16\%)

\begin{tabular}{lcc}
\hline & number & $\%$ \\
Superficial wound infection & 1 & $2 \%$ \\
Discitis & 2 & $4 \%$ \\
Dural tear & 2 & $4 \%$ \\
Dysaethesia & 3 & $6 \%$ \\
\hline
\end{tabular}

Table(3): Other Outcome results:

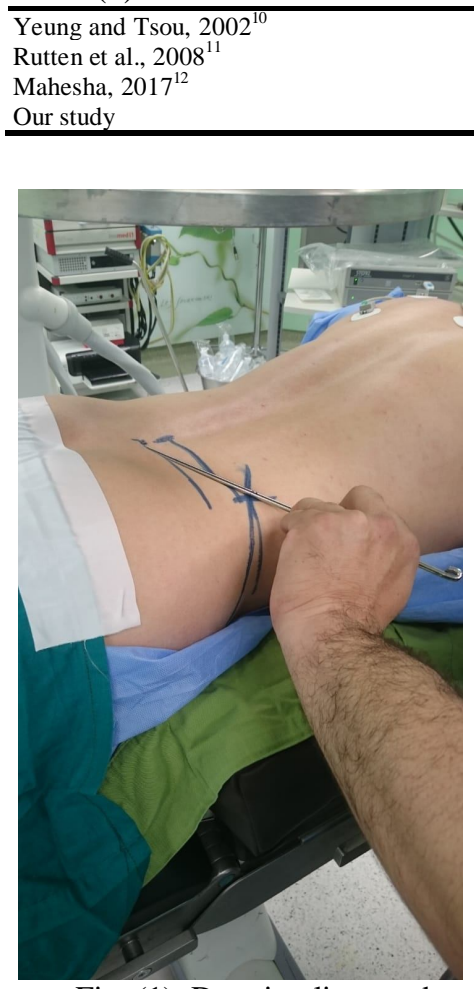

Fig. (1): Drawing lines and determine the dierection of the pathway

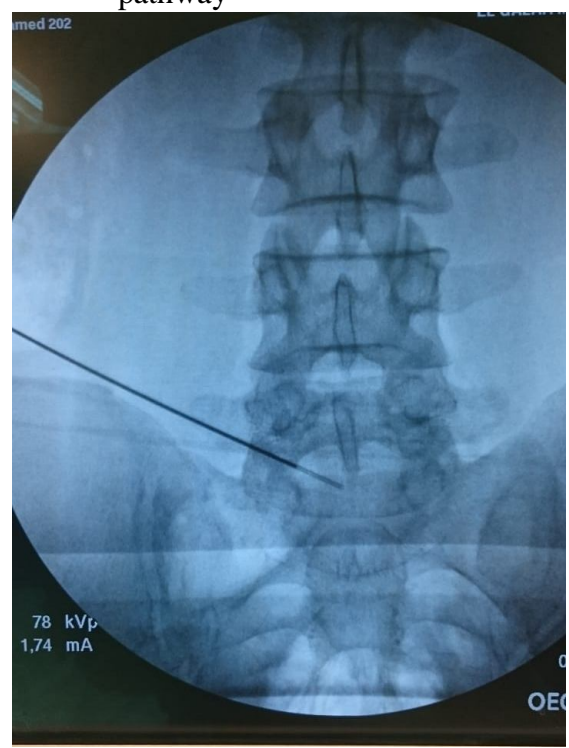

Fig. (4): Guide wire passing through the needle in the disc

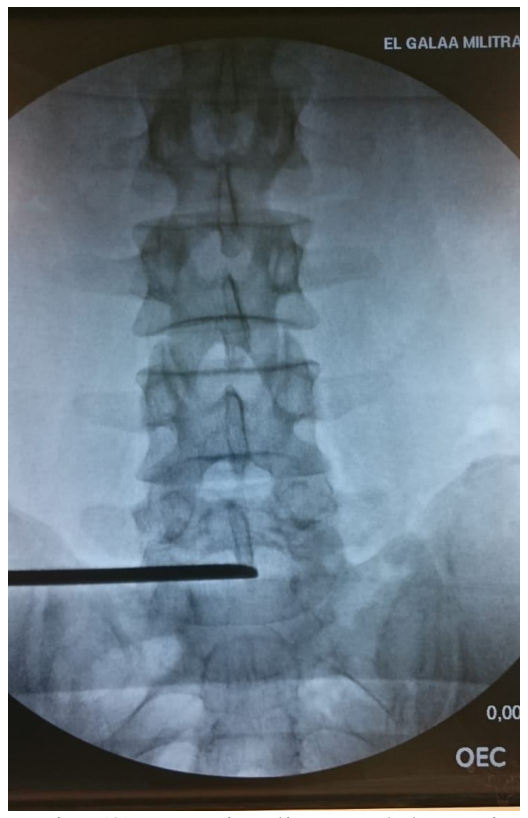

Fig. (2): Drawing lines and determine the dierection of the pathway
$89.7 \%$ satisfactory results

96\% good to excellent (nearly the same microdiscectomy) $96 \%$ satisfactory results

$86 \%$ good to excellent results 


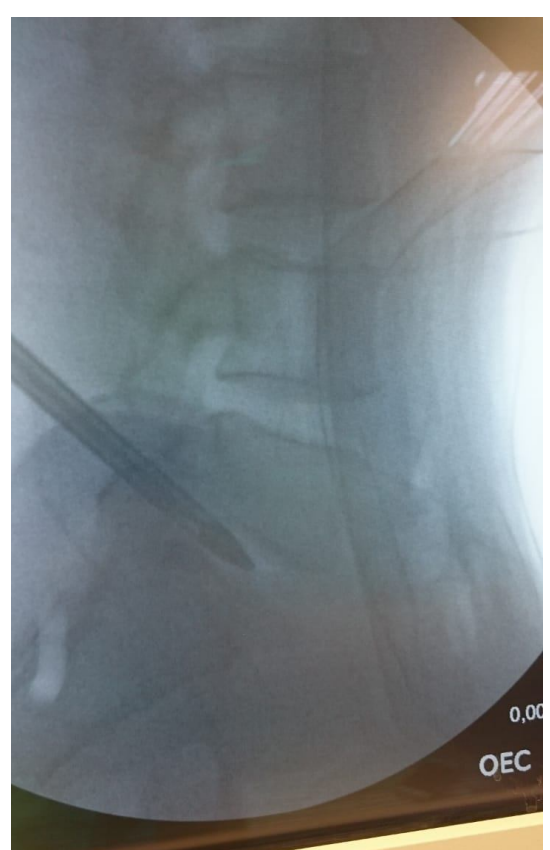

Fig. (6): Obturator advanced into the disc after annular fenestration in Lateral X-ray

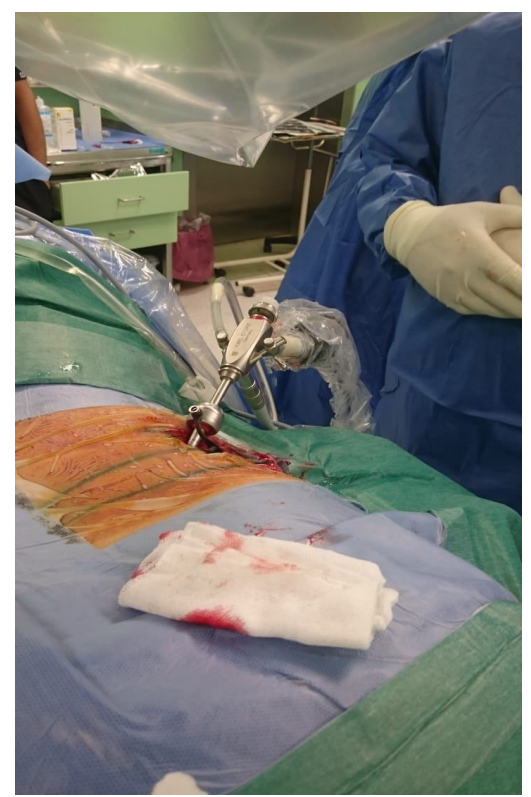

Fig. (8): Intra-operative photo shoed the scope inside the working sheath

\section{Discussion}

Prolapsed intervertebral disc is the most common cause of the lumbosacral pain, which affects the quality of life and functional activity. The microdiscectomy is the most common surgical approach for treatment of sciatica due to herniated lumbar disc $[\mathbf{9 , 1 3}]$.

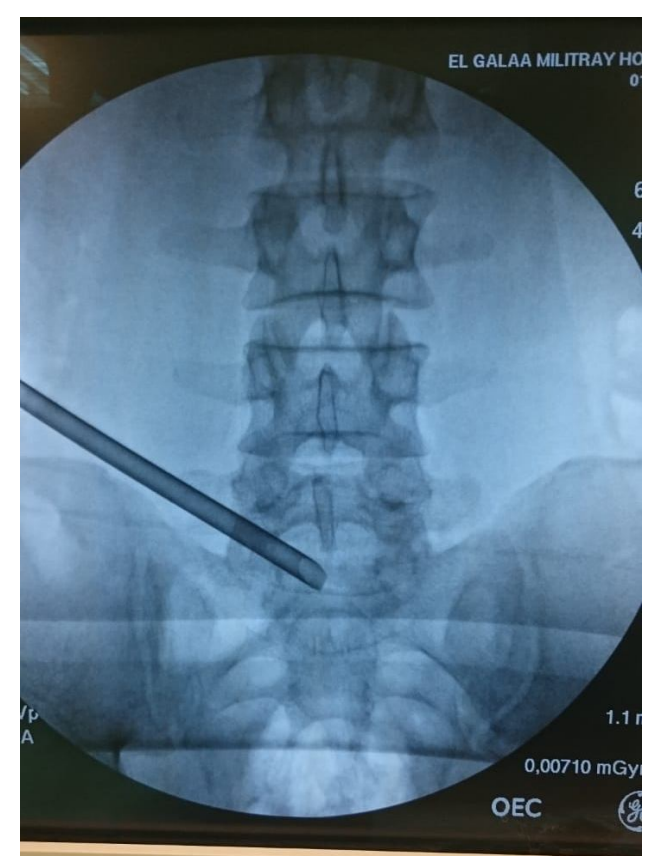

Fig. (7): Working cannula inside the disc in $\mathrm{A} / \mathrm{P} \mathrm{x}-\mathrm{Ray}$

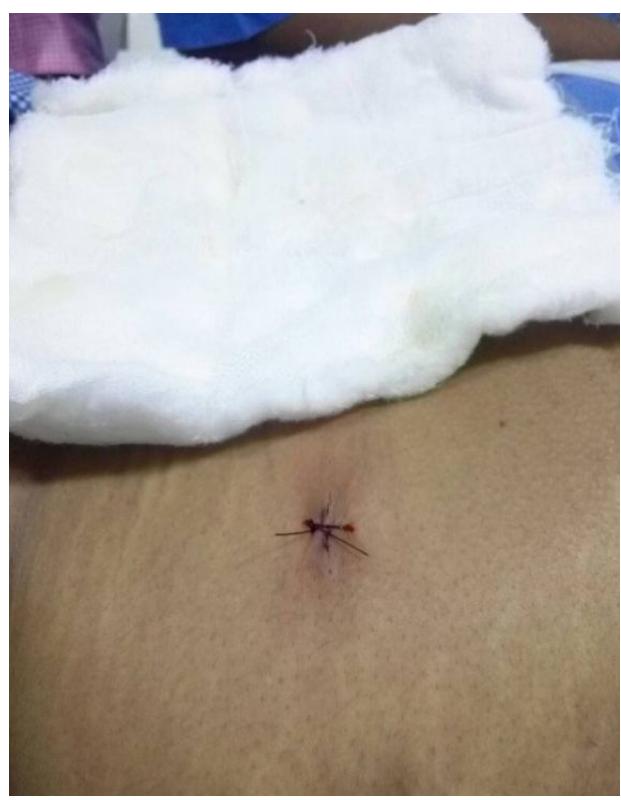

Fig. (9): intr-operative photo showed the closure with one stitch

During the last decades, different types of minimal invasive procedures including the endoscopic ones have been created for surgical treatment of herniated lumbar disc, one of them is the transforaminal endoscopic discectomy through the safe triangle of kambin, which has been developed and become highly advanced recently $[9,10,14]$. 
The Kambin triangle has been identified as a safe working zone in the posterolateral corner of the disc with less muscle, ligamentous damage and without bone or facet resection $[\mathbf{1 0 , 1 4 ]}$.

In our study, the mean age was $41.14 \pm 11.60$ years, male 33 patients $(66 \%)$ and female 17 patients $(34 \%)$ and it is correlated with most of the studies which stated that LDP has a high incidence in males [15].

L4-5 LDP constitutes $68 \%$ of the cases in this study, followed by LS-S1 (18\%) and L3-4 (6\%), and this comparable with other series $[\mathbf{1 2 , 1 6}]$.

The mean operative time in our study was $72.60 \pm 16.90$ minutes which was slightly longer comparable to other studies due to learning curve $[\mathbf{1 2 , 1 7 ]}$,we noticed a long operative time in the first 15 cases which become less during the following cases by improving the skills. Most of studies reported that the learning curve is relatively long which will take time and will shorten with the experience $[8,18]$.

TED has the advantages of minimal surgical trauma and early recovery after surgery so less hospital stay and early return to the work are expected results of the approach. In our study, the mean of hospital stay was $14.76 \pm 11.20$ hours and the mean time to return to work was $26.36 \pm 6.33$ days which are comparable with the reports $[12,17]$.

In this study, 35 patients (70) operated under local anesthesia, and 15 patients(30\%) done under general anesthesia, local anesthesia is a good choice for proper surgeon-patient communication during the procedure which could avoid or minimize any expected injury [9].

In our study, the mean VAS score for sciatica preoperatively, 1, 6, 12 months postoperatively as follow $7.64 \pm \quad 0.76, \quad 2.32 \pm 0.74, \quad 1.80 \pm 0.78$, $1.54 \pm 0.696$ respectively, there was a high significant relation of all post operative values of VAS sciatica when comparing to the preoperative one $(\mathrm{P}<0.001)$.

The mean VAS score for back pain preoperatively, 1,6 , and 12 months postoperatively as follow $6.80 \pm 1.12,2.70 \pm 0.890, \quad 1.68 \pm 0.819$, $1.52 \pm 0.68$ respectively, there was a high Significant correlation between VAS back pain preoperatively and post-operative 1,6,12 months respectively $(\mathrm{P}<0.001)$, the post-operative statistical improvement of the back pain is explained by the truly minimal invasive nature of the approach which doesn't require muscle splitting, nor bone resection [9].

The mean ODI preoperatively, $6 \mathrm{~m} \mathrm{\&}$ 12 months postoperatively as follow $41.68 \pm 0.476$, $23.76 \pm 2.42,14.60 \pm 2.68$, and statistically it was high significant $(\mathrm{P}<0,001)$. In the current study, the marked improvement of back pain, leg pain and the functional status which reported after the operation is consistent with other many randomized control studies which added more advantages of endoscopic procedures as less use of narcotic analgesics, rapid recovery and easy rehabilitation $[10,11,13,19]$. They also noted that the revision of surgery itself after TED is easier due to minimal scarring and relative preserved anatomy $[8,10,19]$ which also noticed by us in the recurrent cases.

In the current study, only one patient had superficial wound infection, two patients $(4 \%)$ has suffered from postoperative discitis, which is comparable with the percentage in other series $[7,10,20,21]$ and dural tear noticed in 2 patients (4\%) which also comparable to the percentage reported in other series [22,23]. Prevalence of accidental dural tear is variable (1.8 to $17.4 \%$ ), and the rate of dural tear decreased with the increase of the experience $[\mathbf{1 8 , 2 3 , 2 4 ]}$. In our study, 5 patients (10\%) suffered from recurrent LDP and sciatica, three of them re-operated later on by microscopic discectomy, the rest two patients have done by endoscopy again and all have doing fine. This rate of recurrence is comparable to some series $[1,17,23,25]$ but higher than which reported in other ones [26,27].

Three (3) patients (6\%) in our study have suffered from dysaethesia, all 3 cases happened in the first 10 cases and relieved within weeks with Gabapentin, after that we have used transforaminal injection by the end of the procedure as a routine and we didn't notice it later on. $6 \%$ dysaethesia in our study is comparable to that reported in other studies [28], but higher than some previous reports $[10,21,23]$.

According to Mac Nab's Outcome Criteria, the overall good to excellent results in our study (43 pt, 86\%), fair (3 pt, 6\%), poor outcome (4 pt, $8 \%)$ and this was comparable with other results discussed the same issue $[\mathbf{1 , 1 0 , 1 3 , 2 5 ]}$, and lower than other outcome results due to the learning curve which needs time to improve $[\mathbf{1 1 , 1 2 , 2 9 ]}$. 
Recommendation: 1) good selection of the patients; 2) patience in learning, because the leanring curve is relatively long.

\section{Conclusion:}

The Percutaneous transforaminal discectomy has been advanced over the last decades and become an accepted, safe and successful choice for management of lumbar disc prolapse and associated sciatica in selected patients, although the microdiscectomy remains the gold standard one.

Limitations of this study are limited number of patients, it is a retrospective study without control group, don't include the entire lumber disc levels.

\section{Compliance with Ethical Standards:}

$>$ Funding: No funding received.

> Conflict of Interest: the authors declare no conflict of interest.

> Ethical approval: approval from the Zagazig University review board (IRB) was taken and all procedures performed in studies were in accordance with the ethical standards of the institutional research committee and with the 1964 Helsinki declaration and its later amendments.

> Informed consent: Informed written consents were obtained from the included patients.

\section{References}

1- GIBSON J.N, COWIE J.G. and IPRENBURG M.: Transforaminal endoscopic spinal surgery: The future 'gold standard' for discectomy? - A review. Surgeo., 10: 290-296, 2012.

2- TZAAN W.C.: Transforaminal percutaneous endoscopic lumbar discectomy. Chang Gung Med. J., 30: 226-34, 2012.

3- OPPENHEIM H. and KRAUSE F.: About the entrapment or strangulation of the cauda equina. Dtsch Med. Wochenschr., 35: 697-700, 1909.

4- MIXTER W.J. and BARR J.S.: Rupture of the intervertebral disc with involvement of the spinal canal. N Engl. J, Med., 211: 210-215, 1934.

5- HIJIKATA S.: Percutaneous nucleotomy. A new concept technique and 12 years' experience. Clin. Orthop. Relat. Res., 238: 9-23, 1989.

6- ONIK G., MOONEY V., MAROON J.C., WILTSE L., HELMS C., SCHWEIGEL J., et al.: Automated percutaneous discectomy: a prospective multiinstitutional study. Neurosurgery, 26: 228-233, 1990.

7- CHOI K.B., LEE C.D. and LEE S.H.: Pyogenic spondylodiscitis after percutaneous endoscopic lumbar discectomy. J. Korean Neurosurg. Soc., 48: 455-460, 2010.

8- ZHANG BIN, SHEN LIU, JUN LIU, et al.: Transforaminal endoscopic discectomy versus conventional microdiscectomy for lumbar disc herniation: a systematic review and meta-analysis. J. Orthop. Surg. Res., 13: 169, 2018.

9- YEUNG A.T.: Minimally Invasive Disc Surgery with the Yeung Endoscopic Spine System (YESS). Surg. Technol. Int., 8: 267-77, 1999.

10-YEUNG A.T. and TSOU P.M.: Posterolateral endoscopic excision for lumbar disc herniation: Surgical technique, outcome, and complications in 307 consecutive cases. Spine (Phila Pa 1976); 27: 722-31, 2002.

11-RUETTEN S., KOMP M., MERK H. and GODOLIAS G.: Full-endoscopic interlaminar and transforaminal lumbar discectomy versus conventional microsurgical technique: A prospective, randomized, controlled study. Spine (Phila Pa 1976). 33: 931-9, 2008.

12-MAHESHA KANTHILA: Percutaneous endoscopic lumbar discectomy: Results of first 100 cases. Indian Journal of Orthopedics, 51 (1): 36-42, 2017.

13-MAYER H.M. and BROCK M.: Percutaneous endoscopic discectomy: surgical technique and preliminary results compared to microsurgical discectomy. J. Neurosurg., 78: 216-225, 1993.

14-KAMBIN P. and GELLMAN H.: Percutaneous lateral discectomy of the upper lumbar spine: A preliminary report. Clin. Orthop., 174: 127-32, 1983.

15-SCHUBERT N. and HOOGLAND T.: Endoscopic transforaminal nucleotomy with foraminoplasty for lumbar disk hernniation. Oper. Orthop. Traumaatol., 17: 641-61, 2005.

16-JANG J.S., AN S.H. and LEE S.H.: Transforaminal percutaneous endoscopic discectomy in the treatment of foraminal and extraforaminal lumbar disc herniations. J. Spinal Disord. Tech., 19: 338-43, 2006.

17-GADJRADJ P.S., VAN TULDER M.W., DIRVEN C.M., et al.: Clinical outcomes after percutaneous transforaminal endoscopic discectomy for lumbar disc herniation: a prospective case series. Neurosurg. Focus, 40: 53, 2016.

18-AHN YONG, IL-TAE JANG and WOO-KYUNG KIM: Transforaminal percutaneous endoscopic lumbar discectomy for high -grade migrated disc 
herniation, Clinical Neurology and Neurosurgery, 147: 11-17, 2016.

19-HERMANTIN F.U., PETERS T., QUARTARARO L. and KAMBIN P.: A prospective, randomized study comparing the results of open discectomy with those of video-assisted arthroscopic microdiscectomy. J. Bone. Joint Surg. Am., 81: 95865, 1999.

20-KAUSHAL M. and SEN R.: Posterior endoscopic discectomy: Results in 300 patients. Indian J. Orthop., 46: 81-85, 2012.

21-GOTECHA S., DEEPAK RANADE, SUJAY VIKHE PATIL, et al.: The role of transforaminal percutaneous endoscopic discectomy in lumbar disc herniations. J. Craniovertebr. Junction Spine, 7(4): 217-223, 2016.

22-KULKARNI A.G., BASSI A. and DHRUV A.: Microendoscopic lumbar discectomy: Technique and results of 188 cases. Indian J. Orthop., 48: 81-87, 2014.

23-ZHU B., YI JIANG, LANPU S., et al.: complications of percutaneous endoscopic lumbar discectomy :experiences and literature review. J. Spine, 6(6): 402, 2017.

24-AHN S.S., KIM S.H. and KIM D.W.: Learning curve of percutaneous endoscopic lumbar discectomy based on the period (Early vs. Late) and technique (in-and-out vs. in-and-out-and-in): A retrospective comparative study. J Korean Neurosurg. Soc., 58: 539-46, 2015.

25-KIM M.J., LEE S.H., JUNG E.S., SON B.G., CHOI E.S., SHIN J.H., et al.: Targeted percutaneous transforaminal endoscopic diskectomy in 295 patients: Comparison with results of microscopic diskectomy. Surg Nweurol., 68: 623-31, 2007.

26-HIRANO Y., MIZUNO J., TAKEDA M., ITOH Y., MATSUOKA $H$. and WATANABE K.: Percutaneous endoscopic lumbar discectomy-early clinical experience. Neurol. Med. Chir., 52: 625-30, 2012.

27-SCHUBERT M. and HOOGLAND T.: Endoscopic transforaminal nucleotomy with foraminoplasty for lumbar disk herniation. Oper. Orthop. Traumatol., 17: 641-61, 2005.

28-CHOI I., AHN J.O., SO W.S., et al.: Exiting root injury in transforaminal endoscopic discectomy: preoperative image considerations for safety. Eur. Spine J., 22:2481-7, 2013

29-CHAE K.H., JU C.I., |LEE S.M., KIM B.W., KIM S.Y. and KIM H.S.: Strategies for noncontained lumbar disc herniation by an endoscopic approach: Transforaminal suprapedicular approach, semi-rigid flexible curved probe, and 3-dimensional reconstruction CT with discogram. J. Korean Neurosurg. Soc., 46: 312-6, 2009. 


\section{الملخص العربى}

\section{استئصال القرص القطني بالتنظير الداخلي عن طريق الجلا: تجربة مبكرة لأول خمسين حالة}

الخلفية: تم استخدام العديد من الأساليب الجراحية لاز اله الغضروف القطنى بدايه من اسنئصال القرص المعياري، واستئصال

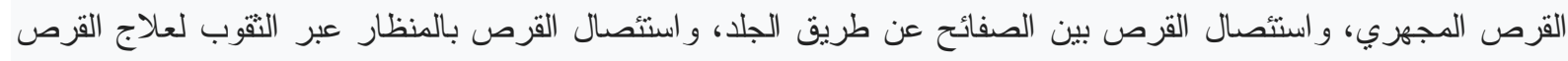
الفقري المتلالي. استئصال القرص بالمنظار عبر المثانة من خلال مثلث كامبين هو إجر اء جر احي بسيط يمكن إجر اؤه تحت تأثير التخدير الموضعي ، دون انقسام العضلات، مع إقامة قصيرة في المستشفى مع الحد الأدنى من المضاعفات. الهدف: الهدف من هذه الدراسة هو ثقييم التجربة المبكرة لاستئصال القرص القطني بالمنظار عبر الثقوب، و التقنية الجر احية،

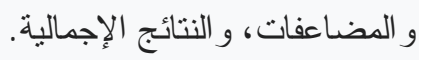
المرضى والطرق: دراسة بأثز رجعي شملت خمسين مريضًا يعانون من آلام أسفل الظهر وعرق النسا من جانب واحد بسبب القرص الفقري المتلي، ونم علاجهم باستئصال القرص عبر المثانة بالمنظار في قسم جراحة الأعصاب (مستشفيات جامعة

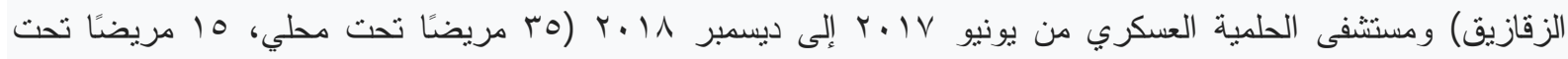

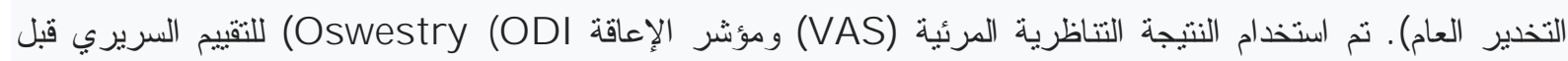

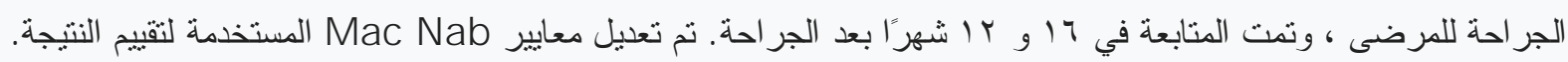

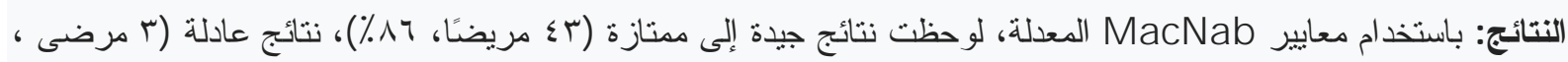

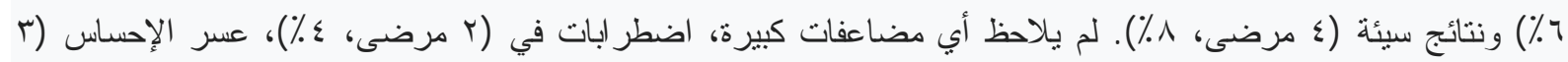

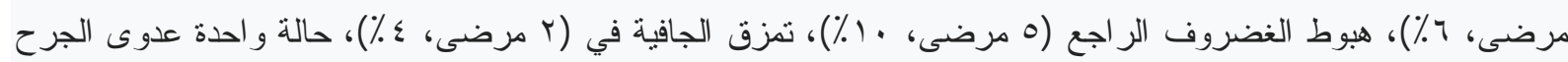

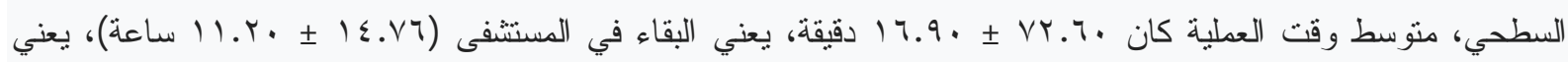

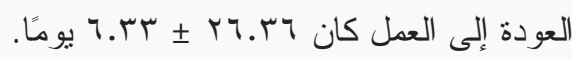
الخلاصة: نم تطوير استئصال القرص عبر الجلد عبر الجلد على مدى العقود الماضية وأصبح خبارًا مقبولًا و آمنًا وناجحًا لإدارة تدلي القرص القطني وعرق النسا المرتبط به في مرضى مختارين ، على الرغم من أن استئصال القرص المجهري يظل المعيار الذهبي. الكلمات المفتاحية: عبر الثقوب، بالمنظار - كامبين - قطني - استنئصال القرص. 